\title{
On the Passing of Angus Campbell
}

ANGuS CAMPBELL, A PIONEER in the application of survey research to a variety of social science disciplines, passed away of a sudden heart attack on the evening of December 14,1980, at the age of 70 . He had been a founder and long-term director of the Survey Research Center at the University of Michigan, and later the director of its parent organization, the Institute for Social Research.

Although his graduate training at Stanford in the early 1930s was as an experimental psychologist under figures like Ernest R. Hilgard and Kurt Lewin, his first teaching assignments at Northwestern University before World War II whetted his interests in sociology and anthropology, and he began to move into social psychology. This shift was completed when, early in the War, he joined the group under Rensis Likert at the Division of Program Surveys at the Department of Agriculture. The Division was engaged in monitoring the reactions of the American population to aspects of the war effort through national sample surveys. First as an interviewer in the field and later as an administrator, Campbell learned all phases of the new survey research techniques to which the rest of his scholarly life would be dedicated.

After the War the central figures at the Division moved from government back to the academy at the University of Michigan. Campbell became the first director of the Survey Research Center there. In the ensuing 30 years under his kind and insightful guidance, the Center grew from a tiny and struggling organization into the largest university-based research organization of its kind in the social sciences, and a full-fledged national institution.

While Campbell had few peers as a research administrator, at the same time he maintained an extraordinarily vigorous second career as a productive scholar, one much more visible to the outside world. Soon after his arrival in Ann Arbor, he began to develop within the Survey Research Center a program for studies in political behavior, built around sample surveys of the electorate at the time of biennial national elections. In a series of collaborative monographs from the program culminating in The American Voter (1960) he made a range of conceptual contributions which have left a major imprint in the discipline of political science. Although he turned his personal research attention from this program in the middle of the $1960 \mathrm{~s}$, the research team he had organized and its programmatic research had taken deep root, and a decade later the National Election Studies were declared a "national resource" by the National Science Foundation, the first such designation for a social science enterprise. 
The onset of public turmoil in the 1960s captured Campbell's concern about race relations in the United States. In response to a request from the National Commission on Civil Disorders, he undertook with Howard Schuman a study of race problems in 15 major cities, several of which had experienced severe rioting. Once again, his work took root, and the Institute has been monitoring trends in racial attitudes ever since.

In the final decade of his life, Campbell launched an ambitious effort to conceptualize and measure the perceived quality of life in the American population. He was concerned to establish a series of measurements bearing on the sense of fulfillment and frustration experienced by the population in various domains of their everyday lives, including not only their economic situations, but their marriages, friendships and communities as well. The first round of data collections on the subject was reported in 1976 as The Quality of American Life.

He was working on the second round of these measurements at the time of his death. Although he had retired from his post as director of the Institute for Social Research in 1976, he had merely redoubled the pace of his own research. His newest book on The Sense of Well-Being in America (New York: McGraw-Hill, 1981) had just been published, and he spent the last week of his life in fine health at his desk beginning a new study of the quality of life of those in their later years.

Campbell was visionary in his emphasis on cumulative programmatic research in the social sciences, and in his own effortlessly interdisciplinary approach to the understanding of man and society. His capacious interests and research productivity made him a scholar of international renown, and those whose lives he touched more personally found him an inspiring and dear friend. He shall be sorely missed by the myriad of scholars who knew him, although his life was to the end a model of the kind of personal fulfillment he wished for all.

\section{PhILIP E. CONVERSE*}

-[Philip E. Converse, Ph.D., program director of the Center for Political Studies, Institute for Social Research, University of Michigan, is Robert C. Angell Professor of Political Science and Sociology of the University of Michigan, Ann Arbor, Mich. 48106.]

\section{A Journal for Business Etbics}

The D. Reidel Publishing Company of Dordrecht, Holland, and 190 Old Derby St., Hingham, Mass. 02043 has announced that it will establish a quarterly Journal of Business Ethics in 1982. The editor is Alex C. Michalos. 
Copyright of American Journal of Economics \& Sociology is the property of Blackwell Publishing Limited. The copyright in an individual article may be maintained by the author in certain cases. Content may not be copied or emailed to multiple sites or posted to a listserv without the copyright holder's express written permission. However, users may print, download, or email articles for individual use. 